\title{
PCR detection of Burkholderia multivorans in water and soil samples
}

\author{
Charlotte Peeters ${ }^{1}$, Stijn Daenekindt ${ }^{2,3}$ and Peter Vandamme ${ }^{1 *}$ (iD
}

\begin{abstract}
Background: Although semi-selective growth media have been developed for the isolation of Burkholderia cepacia complex bacteria from the environment, thus far Burkholderia multivorans has rarely been isolated from such samples. Because environmental B. multivorans isolates mainly originate from water samples, we hypothesized that water rather than soil is its most likely environmental niche. The aim of the present study was to assess the occurrence of B. multivorans in water samples from Flanders (Belgium) using a fast, culture-independent PCR assay.

Results: A nested PCR approach was used to achieve high sensitivity, and specificity was confirmed by sequencing the resulting amplicons. B. multivorans was detected in $11 \%$ of the water samples $(n=112)$ and $92 \%$ of the soil samples $(n=25)$ tested. The percentage of false positives was higher for water samples compared to soil samples, showing that the presently available B. multivorans recA primers lack specificity when applied to the analysis of water samples.
\end{abstract}

Conclusions: The results of the present study demonstrate that B. multivorans DNA is commonly present in soil samples and to a lesser extent in water samples in Flanders (Belgium).

Keywords: Burkholderia multivorans, PCR assay, recA, Environmental samples

\section{Background}

The Burkholderia cepacia complex (Bcc) represents a group of closely related $[1,2]$ and extremely versatile bacteria that can be applied for a range of bioremediation, plant growth promotion and biocontrol purposes [3]. Yet, these bacteria are simultaneously rare but important opportunistic pathogens in cystic fibrosis $(\mathrm{CF})$ patients $[4,5]$. The most prevalent Bcc CF pathogens are Burkholderia cenocepacia and Burkholderia multivorans. The low number of outbreaks caused by $B$. multivorans [6-8], and the fact that $B$. multivorans isolates from $\mathrm{CF}$ patients commonly represent unique strains, suggest that there is only limited person-to-person transmission, and that strains are acquired from non-human sources such as the natural environment [9]. Although many studies have described the isolation of $B$. cenocepacia from rhizosphere samples [10], only few reported on the occasional isolation of $B$. multivorans from environmental samples [11-14]. Consequently, the true environmental niche of $B$.

\footnotetext{
* Correspondence: Peter.Vandamme@UGent.be

${ }^{1}$ Laboratory of Microbiology, Department of Biochemistry and Microbiology, Ghent University, Ghent, Belgium

Full list of author information is available at the end of the article
}

multivorans is considered unknown. The fact that the few environmental B. multivorans isolates that have been reported mainly originated from water samples [12, 14] suggested that water is the most likely environmental niche of $B$. multivorans.

PCR-based diagnostic tests have been developed for Bcc species identification based on both the 16S rRNA and rec $A$ genes, resulting in two sets of species-specific primers for B. multivorans [15, 16]. Miller et al. [17] used the 16S rRNA based PCR assays for the cultureindependent detection of $\mathrm{Bcc}$ in soil environments. In the latter study, none of the samples that were Bcc PCR positive yielded Bcc isolates, suggesting that cultivationdependent methods for the detection of Bcc bacteria may underestimate environmental populations.

In the present study, we used a cultivation-independent recA-based PCR assay to assess the presence of $B$. multivorans in water and soil samples in Flanders, Belgium. Our results show that $B$. multivorans DNA could be detected only occasionally in water samples but to a greater extent in soil samples, and that the available $B$. multivorans recA primers lack specificity, especially when applied to the analysis of water samples. 


\section{Results}

\section{Specificity of the $16 \mathrm{~S}$ rRNA and recA PCR assays}

Preliminary experiments were performed to compare the specificity of the $B$. multivorans-specific primers that were available from previous studies $[15,16]$. Therefore, PCR assays based on the $r e c A$ and $16 \mathrm{~S}$ rRNA genes were applied to DNA extracts of two water samples and the resulting amplicons were sequenced. The obtained sequences were analyzed using the NCBI blastn suite (blast.ncbi.nlm.gov) to evaluate specificity. For amplicons of the recA PCR assay, hits showed $98 \%$ or more similarity with the recA sequence of $B$. multivorans ATCC 17616 (CP000868) (this degree of variability in $r e c A$ gene sequences corresponds with the sequence diversity commonly observed within Bcc species [18]). For the $16 \mathrm{~S}$ rRNA nested PCR, amplicons showed the highest similarity (96 \%) with sequences of Comamonadaceae sp. (FM886892), Ideonella sp. (FM886860), Roseatales sp. (JQ917995), and Mitsuaria sp. (JQ659937), all belonging to the order Burkholderiales, yet demonstrating that the nested 16S rRNA PCR assay was not B. multivorans specific. Therefore, only the $B$. multivorans nested recA PCR assay was further optimized (i.e., PCR mix, BSA concentration, number of cycles, primer concentration and quantity of pooled PCR product being transferred to the second round of PCR; data not shown) and used to analyze all environmental samples.

\section{Detection of $B$. multivorans in environmental samples}

All 112 water samples yielded PCR-grade DNA extracts without the need of an extra purification step. B. multivorans DNA was detected in 12 water samples (11\%), of which one sample (W132) already yielded a visible amplicon in the first round of PCR (showing $97 \%$ similarity to the $\operatorname{rec} A$ sequence of $B$. multivorans ATCC 17616). For the soil samples $(n=27)$, four yielded PCRgrade DNA without the need of an extra purification step, 21 samples needed extra purification using agarose plugs, and for two soil samples (S6 and S14) no PCRgrade DNA extract could be obtained. The latter soil samples were therefore excluded from the dataset. For soil DNA extracts containing $50 \mathrm{ng} / \mu \mathrm{l}$ or more DNA, an $\mathrm{OD}_{320 / 260}$ ratio of 0.15 or higher was a good indicator for the necessity of an extra purification step to obtain PCR-grade DNA. B. multivorans DNA was detected in 23 soil samples (92\%), of which none yielded a visible amplicon in the first round of PCR.

\section{Statistical data analysis}

The first model tested if type (water, soil) and class (SRW, CRS, O) were significant predictors for B. multivorans detection. Binomial logistic regression showed that the type of sample (water versus soil) was indeed a significant predictor for B. multivorans detection (Table 1). Adding
Table 1 Binomial logistic regression model 1 (water and soil samples)

\begin{tabular}{lll}
\hline & Beta (SE) & Odds ratio $(95 \% \mathrm{Cl})$ \\
\hline Intercept & $-2.12^{* * *}(0.31)$ & $0.12(0.06 ; 0.21)$ \\
Type & & \\
$\quad$ Water (ref) & - & - \\
$\quad$ Soil & $4.56^{* * *}(0.80)$ & $95.83(24.48 ; 646.70)$ \\
Chi $^{2}$ & $65.50^{* * *}(\mathrm{df}=1)$ & \\
\hline
\end{tabular}

Binomial logistic regression with $\mathrm{Bm}$ as outcome and Type as predictor Signif. codes: $0^{\prime * * * \prime} 0.001^{* * *} 0.01^{* * \prime} 0.05 \prime$.'

SE standard error, $\mathrm{Cl}$ confidence interval

class to the model did not significantly improve the model (data not shown). The odds ratio from this model predicted that there was a 96 times $\left(\mathrm{e}^{4.56}=95.58\right)$ bigger chance to detect $B$. multivorans in soil than in water samples.

To test which characteristics of the water environment affected the presence of $B$. multivorans, a second model was tested in which $\mathrm{pH}$, temperature and class were assessed as predictors for B. multivorans detection. Binomial logistic regression showed that $\mathrm{pH}$ and class were significant predictors for $B$. multivorans detection in water samples (Table 2). Model 2a includes the main effects of all the variables and shows that the probability of detecting $B$. multivorans was higher in water samples with high $\mathrm{pH}$. The results also show that the probability of detecting $B$. multivorans was higher in streams (CRS) compared to swimming and recreational waters (SRW). Model 2b includes an additional interaction effect between temperature and $\mathrm{pH}$ to test whether the effect of $\mathrm{pH}$ on detection depends on the temperature. The model fit of model $2 \mathrm{~b}$ improved and the interaction effect between temperature and $\mathrm{pH}$ indicated that the positive effect of $\mathrm{pH}$ was stronger when the temperature of the water was higher.

Table 2 Binomial logistic regression model 2 (water samples)

\begin{tabular}{|c|c|c|c|}
\hline & \multirow{2}{*}{$\begin{array}{l}\text { Model 2a } \\
\text { Beta (SE) }\end{array}$} & \multicolumn{2}{|c|}{ Model 2b } \\
\hline & & Beta (SE) & Odds ratio $(95 \% \mathrm{Cl})$ \\
\hline Intercept & $-2.72^{* * *}(0.59)$ & $-3.51^{* * *}(0.82)$ & $0.03(0.00 ; 0.01)$ \\
\hline $\mathrm{pH}$ & $0.97 \cdot(0.52)$ & $1.70^{*}(0.69)$ & $5.48(1.52 ; 23.84)$ \\
\hline Temperature & $-0.22(0.16)$ & $-0.19(0.16)$ & $0.83(0.59 ; 1.13)$ \\
\hline \multicolumn{4}{|l|}{ Class } \\
\hline SRW (ref) & - & - & - \\
\hline $\mathrm{O}$ & $-0.18(0.92)$ & $0.16(0.96)$ & $1.17(0.14 ; 7.29)$ \\
\hline CRS & $1.47 .(0.80)$ & $1.95^{*}(0.94)$ & $7.06(1.21 ; 52.19)$ \\
\hline \multicolumn{4}{|l|}{ Interaction } \\
\hline pH Temperature & - & $0.39^{*}(0.20)$ & $1.47(1.01 ; 2.25)$ \\
\hline $\mathrm{Chi}^{2}$ & $8.24 .(d f=4)$ & $12.36^{*}(\mathrm{df}=5)$ & \\
\hline
\end{tabular}

Binomial logistic regression with $\mathrm{Bm}$ as outcome and $\mathrm{pH}$, Temperature and Class as predictor, without (model $2 \mathrm{a}$ ) and with (model $2 \mathrm{~b}$ ) interaction effect between $\mathrm{pH}$ and Temperature

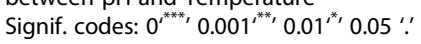

SE standard error, $\mathrm{Cl}$ confidence interval, SRW swimming or recreational water, CRS canal-river-stream, $O$ other 


\section{Detection limit recA PCR assay}

The recA PCR assay was applied to serial dilutions of genomic DNA from B. multivorans R-20526 to determine its detection limit. The highest $50 \times$ dilution testing positive was the fourth one, from which a twofold dilution series was made. The highest twofold dilution testing positive in all three replicate runs of the assay was the second one, containing 1.35 genome equivalents $/ \mu \mathrm{l}$. Given that $r e c A$ is a single-copy gene, and that for each dilution $2 \times 2 \mu \mathrm{l}$ was added to the first round of PCR (set up in duplicate), the detection limit was determined to be $5.41 \mathrm{rec} A$ copies.

\section{Discussion}

Because the goal of the present study was to gain insight in the environmental niche of $B$. multivorans in a time and cost-effective way, we chose for a conventional PCR method with gel-based detection of the resulting amplicons, instead of quantitative PCR. B. multivorans-specific primers based on both $16 \mathrm{~S}$ rRNA and recA sequences were available from previous studies $[15,16]$. Although the recA gene has a higher taxonomic resolution [16], a 16S rRNA gene based assay is potentially more sensitive because the $B$. multivorans genome contains five copies of the 16S rRNA gene [19]. However, preliminary tests revealed that the $16 \mathrm{~S}$ rRNA based assay yielded only false positive results, as shown by sequence analysis of the resulting amplicons. A nested PCR design was used to increase the sensitivity of the recA PCR assay [20], in which the first PCR was carried out in duplicate and the resulting PCR product was pooled before using it as a template in the second PCR. The in vitro detection limit of this PCR assay was therefore determined to be 5.41 recA copies or genome equivalents.

The specificity of the $r e c A$ primers [16] used was previously evaluated [21]. The latter study demonstrated that non-specific primer binding could be eliminated by raising the annealing temperature for the $B$. multivorans assay from $58{ }^{\circ} \mathrm{C}$ to $64{ }^{\circ} \mathrm{C}$, resulting in a specificity of $100 \%$ [21]. Additionally, the combination of two different primer pairs in our nested PCR design (specific for the Bcc and B. multivorans) further minimized false positive results. Finally, all resulting amplicons were sequenced to ensure that only true positive results were recorded. Whereas this final check yielded satisfactory results for the soil samples (one false positive versus 23 true positives), it revealed a strikingly high number of false positives for the water samples (20 false positives versus 12 true positives). The false positives included samples for which the amplicon could not be sequenced (one soil sample and 15 water samples) or samples for which the resulting sequence did not yield any blast hits (five water samples). These findings demonstrate that this rec $A$-based PCR assay in its current form is not suited for routine analysis of water samples, and that one should re-evaluate PCR-based methods in terms of specificity when applying them to environmental samples [22].

To eliminate false negative results caused by PCR inhibitors such as humic acids in the environmental DNA extracts, all samples were screened for the presence of PCR inhibitors using a universal $16 \mathrm{~S}$ rRNA PCR. In case this universal PCR was inhibited, the DNA extracts were purified using low-melting point agarose plugs. Re-testing the DNA extracts after this purification step demonstrated that this purification procedure was very efficient in removing the humic acids from the DNA extracts, as shown previously by Moreira [23]. Furthermore, optical density should not only be measured at $260 \mathrm{~nm}$ because this can lead to an overestimation of the DNA concentration if humic acids are present, but also at $320 \mathrm{~nm}$ to quantify these contaminations and to evaluate the quality of environmental DNA extracts properly [24, 25].

Because the few environmental $B$. multivorans isolates that have been reported mainly originated from water samples [12, 14], we hypothesized that water rather than soil was the most likely environmental niche of $B$. multivorans. Our study therefore focused primarily on water samples. However, only 12 out of 112 water samples (11\%) examined were B. multivorans PCR positive, in contrast to 23 out of 25 soil samples (92\%) examined. Despite the small number of soil samples, binomial logistic regression showed a highly significant effect $(p<.001)$ of the type of sample (Model 1, Table 1) and predicted that there was a 96 times bigger chance to detect $B$. multivorans in soil than in water samples. This result also seemed to suggest that, if present, $B$. multivorans can be isolated more easily from water than from soil samples. Accordingly, Miller et al. [17] showed that although a high percentage of soil samples was PCR positive for Bcc, none of these samples yielded Bcc isolates, demonstrating that cultivation-dependent recovery of Bcc bacteria likely underestimates their prevalence in environmental samples. However, the detection of B. multivorans DNA does not necessarily imply that viable target organisms were present at the moment samples were taken [26].

Binomial logistic regression showed that the probability of detecting $B$. multivorans in water samples was higher in streams (CRS) compared to swimming and recreational waters (SRW), and in water samples with a higher $\mathrm{pH}$ (Model 2, Table 2). Since $\mathrm{pH}$ is known to be an important predictor of bacterial diversity in soil [27, 28], and Burkholderia bacteria have been shown to be acid tolerant [29], we expected to detect more B. multivorans in acidic versus alkaline waters. The opposite findings of the present study again may suggest that water is not the natural reservoir of $B$. multivorans. However, the number of PCR positive water samples was rather small and therefore one should be careful 
when extrapolating the results of our binomial logistic regression model 2.

Our finding that $B$. multivorans is widely distributed in soil samples contrasts with the results of previous isolation campaigns, but nevertheless agrees with the notion that the soil environment typically harbors large-genome sized organisms [30, 31]. As B. multivorans harbors a $\sim 6.5 \mathrm{Mb}$ genome, it is equipped with the metabolic versatility needed to thrive in a complex, variable environment such as soil. Future research could focus on the genome biology of this organism, and try to infer the lifestyle of this organism based on genome data [32,33].

\section{Conclusions}

In summary, we applied a recA-based PCR assay that demonstrated that $B$. multivorans DNA is widely distributed in soil samples but only occasionally in water samples in Flanders, Belgium. As for all Bcc bacteria it is unclear if and how this mere observation should be implemented in infection control guidelines. Our study also demonstrated that the presently available $B$. multivorans recA primers lack specificity when applied to the analysis of water samples.

\section{Methods}

\section{Samples}

Water $(n=112)$ and soil $(n=27)$ samples were taken from August to October 2013 in Flanders, Belgium (Additional file 1). For the water samples, an autoclaved $1 \mathrm{~L}$ Duran bottle was opened and filled $10 \mathrm{~cm}$ below the water surface. Per sample, three times $150 \mathrm{ml}$ was filtered using a Nalgene vacuum filter funnel and cellulose nitrate membrane filters with $0.45 \mu \mathrm{m}$ pore size and $47 \mathrm{~mm}$ diameter (Thermo Scientific). For the soil samples, samples were taken $2 \mathrm{~cm}$ below the soil surface using a sterile spoon, and collected in sterile falcon tubes. Per sample, $1 \mathrm{~g}$ of soil was homogenized in $9 \mathrm{ml}$ phosphate-buffered resuspension buffer $(0.15 \mathrm{M} \mathrm{NaCl}$, $10 \mathrm{mM}$ EDTA, $0.1 \mathrm{M}$ phosphate buffer, $\mathrm{pH}$ 8.0) using a Stomacher blender for $30 \mathrm{~s}$ at $230 \mathrm{rpm}$. Three times $1 \mathrm{ml}$ of soil suspension was transferred to an Eppendorf tube and centrifuged for $5 \mathrm{~min}$ at 13,000 rpm (17,949 g) before removing the supernatant. Filters and soil pellets were stored at $-20{ }^{\circ} \mathrm{C}$ until DNA extraction.

For each sample, sampling date, address, region (i.e., West-Vlaanderen [WV], Oost-Vlaanderen [OV], Limburg $[\mathrm{L}]$, Vlaams-Brabant [VB] or Antwerpen [A]), and class (i.e., swimming or recreational water [SRW], canal-riverstream [CRS] or other [O]) were recorded (Additional file 2). Swimming and recreational waters were those under surveillance of the Flemish Environment Agency (www.kwaliteitzwemwater.be). For water samples, $\mathrm{pH}$ and temperature were measured on site. For soil samples, $\mathrm{pH}$ was measured after dissolving $10 \mathrm{~g}$ of soil in $50 \mathrm{ml}$ distilled water and magnetic stirring for $10 \mathrm{~min}$.
DNA extraction from environmental samples and quality assessment

Prior to DNA extraction, filters with biological material from water samples were cut into smaller pieces with sterilized scissors. Total DNA was extracted in triplicate from the filters and soil pellets (three per sample) following the protocol for Gram-negative bacteria of Pitcher et al. [34]. DNA pellets were dissolved by adding 50 or $100 \mu \mathrm{l}$ TE buffer depending on the size of DNA pellet, and left to dissolve overnight at $4{ }^{\circ} \mathrm{C}$. RNA was degraded by adding 2.5 or $5 \mu \mathrm{l}$ RNase $(2 \mathrm{mg} / \mathrm{ml})$ for pellets dissolved in 50 or $100 \mu \mathrm{l} \mathrm{TE}$, respectively, and incubating at $37^{\circ} \mathrm{C}$ for $1 \mathrm{~h}$.

The quality and quantity of the extracted DNA were examined by measuring optical densities (OD) at $234 \mathrm{~nm}, 260 \mathrm{~nm}, 280 \mathrm{~nm}$ and $320 \mathrm{~nm}[24,25]$ with a SpectraMax Plus 384 spectrophotometer. DNA was considered of acceptable quality if the $\mathrm{OD}_{260 / 280}$ ratio was higher than 1.7, the $\mathrm{OD}_{234 / 260}$ ratio was smaller than 1 and the $\mathrm{OD}_{320 / 260}$ ratio was smaller than 0.15 . If both quality and quantity of the three DNA extraction replicates per sample were similar, these replicates were pooled. DNA fragmentation and RNA contamination was assessed by agarose (1 \%) gel electrophoresis and EtBr staining.

To test for the presence of PCR inhibitors, DNA extracts were subjected to a $16 \mathrm{~S}$ rRNA amplification PCR with universal primers ARI C/T (5'-CTG GCT CAG GAY GAA CGC TG-3') and pH (5'-AAG GAG GTG ATC CAG CCG CA-3'). The PCR mix contained $1 \times$ CorelLoad PCR buffer (Qiagen), $0.2 \mathrm{mM}$ dNTP (Applied Biosystems), 0.5 U AmpliTaq (Applied Biosystems) $0.1 \mu \mathrm{M}$ of both primers and $200 \mathrm{ng} / \mu \mathrm{l} \mathrm{BSA}$ (Roche). For each sample, $2 \mu \mathrm{l}$ DNA was added to $23 \mu \mathrm{l}$ PCR master mix. B. multivorans R-20526 DNA and sterile MQ were used as positive and negative control, respectively. PCR was performed using a MJ Research PTC-100 thermal cycler. Initial denaturation for $5 \mathrm{~min}$ at $95{ }^{\circ} \mathrm{C}$ was followed by 3 cycles of $1 \mathrm{~min}$ at $95{ }^{\circ} \mathrm{C}$, $2 \mathrm{~min} 15 \mathrm{~s}$ at $55^{\circ} \mathrm{C}$ and $1 \mathrm{~min} 15 \mathrm{~s}$ at $72{ }^{\circ} \mathrm{C}$, another 30 cycles of $35 \mathrm{~s}$ at $95^{\circ} \mathrm{C}, 1 \mathrm{~min} 15 \mathrm{~s}$ at $55^{\circ} \mathrm{C}$ and $1 \mathrm{~min}$ $15 \mathrm{~s}$ at $72{ }^{\circ} \mathrm{C}$, and a final elongation for $7 \mathrm{~min}$ at $72{ }^{\circ} \mathrm{C}$. The presence of amplicons was verified via agarose $(1 \%)$ gel electrophoresis with SmartLadder (Eurogentec) as molecular size marker and EtBr staining.

If the $\mathrm{OD}_{320 / 260}$ ratio was higher than 0.15 and/or no universal 16S rRNA amplicon could be obtained, an extra purification step using agarose plugs was performed to remove humic acids and other PCR inhibiting contaminants [23]. After purification using plugs, DNA extracts were diluted $5 x$ in TE buffer. Only DNA extracts for which a universal 16S rRNA amplicon could be obtained, were subjected to the $B$. multivorans PCR assay. 


\section{Preliminary experiment}

A preliminary experiment compared the specificity of the $B$. multivorans-specific primers that were based on the $r e c A$ and $16 \mathrm{~S}$ rRNA gene and were available from previous studies $[15,16]$. Sampling of two water samples, DNA extraction and quality assessment of the DNA extracts was performed as described above. For the nested B. multivorans $16 \mathrm{~S}$ rRNA PCR assay, PCR products of the first, universal 16S rRNA PCR were used as template in a second PCR in which B. multivoransspecific primers BC-GII (5'- AGG CGG TCT GTT AAG ACA - $\left.3^{\prime}\right)$ and BC-R (5'- AGC ACT CCC GAA TCT CTT $-3^{\prime}$ ) were used [15]. The second PCR mix was identical to the first PCR mix, except for a lower BSA concentration $(50 \mathrm{ng} / \mu \mathrm{l})$. For each sample, $2 \mu \mathrm{l}$ PCR product of the first PCR was added to $23 \mu$ PCR master mix. The positive (B. multivorans R-20526) and negative (blank) control of the first PCR $(5 \mu \mathrm{l})$ were also transferred as template into the second PCR. The thermal cycling program was identical to that of the first PCR. The presence of amplicons was verified via agarose (1\%) gel electrophoresis with SmartLadder (Eurogentec) as molecular size marker and $\mathrm{EtBr}$ staining. If an amplicon (445 bp) was visible in the second PCR, it was sequenced using the BC-GII and BC-R primers as described previously [35] to exclude false positive results. The recA based B. multivorans PCR assay was performed as described below.

\section{Nested recA PCR assay for $B$. multivorans}

In a first PCR, Bcc-specific recA primers recA-01-F (5'GAT AGC AAG AAG GGC TCC-3') and recA-02-R (5'-CTC TTC TTC GTC CAT CGC CTC-3') were used [36]. The PCR mix contained $1 \times$ CorelLoad PCR buffer (Qiagen), $0.25 \mathrm{mM}$ dNTP (Applied Biosystems), $1 \mathrm{U}$ Taq (Qiagen), $0.5 \mu \mathrm{M}$ of both primers, 1× Q-solution (Qiagen) and $200 \mathrm{ng} / \mu \mathrm{l} \mathrm{BSA}$ (Roche). For each sample, $2 \mu \mathrm{l}$ DNA was added to $23 \mu \mathrm{l}$ PCR master mix. B. multivorans R-20526 DNA and sterile MQ were used as positive and negative control, respectively. This PCR reaction was setup in duplicate for each sample to enable pooling and to increase sensitivity. PCR was performed using a MJ Research PTC-100 thermal cycler. Initial denaturation for $2 \mathrm{~min}$ at $94{ }^{\circ} \mathrm{C}$ was followed by 35 cycles of $30 \mathrm{~s}$ at $94{ }^{\circ} \mathrm{C}$, $45 \mathrm{~s}$ at $58^{\circ} \mathrm{C}$ and $1 \mathrm{~min}$ at $72{ }^{\circ} \mathrm{C}$, and a final elongation for $10 \mathrm{~min}$ at $72{ }^{\circ} \mathrm{C}$. PCR product of the duplicate reactions for each sample were pooled using filter tips and used as template in the second PCR, in which B. multivorans-specific primers BCRBM1 (5'-CGG CGT CAA CGT GCC GGA T$\left.3^{\prime}\right)$ and BCRBM2 (5' ${ }^{\prime}$ TCC ATC GCC TCG GCT TCG T$3^{\prime}$ ) were used [16]. The second PCR mix was identical to the first PCR mix, except for a lower BSA concentration $(50 \mathrm{ng} / \mu \mathrm{l})$ and a higher primer concentration $(1 \mu \mathrm{M})$. For each sample, $5 \mu \mathrm{l}$ of pooled PCR product from the first
PCR was added to $20 \mu \mathrm{l}$ PCR master mix. The positive (B. multivorans R-20526) and negative (blank) control of the first PCR $(5 \mu \mathrm{l})$ were also transferred as template into the second PCR. Thermal cycling was identical to the first $\mathrm{PCR}$, except that the annealing temperature was $64{ }^{\circ} \mathrm{C}$ instead of $58{ }^{\circ} \mathrm{C}$ [21]. The presence of amplicons was verified via agarose $(1 \%)$ gel electrophoresis with SmartLadder (Eurogentec) as molecular size marker and $\mathrm{EtBr}$ staining. The nested recA PCR assay was performed twice for each sample. If the results for the two runs were not the same, the assay was performed a third time. If an amplicon (714 bp) was visible in the second B. multivorans-specific PCR, it was sequenced using the BCRBM1 and BCRBM2 primers as described previously [35] to exclude false positive results. Only if at least for one of the replicate runs an amplicon from the second PCR was sequenced that showed at least $97 \%$ similarity to the $r e c A$ sequence of $B$. multivorans ATCC 17616, the sample was considered a true positive for the detection of B. multivorans.

To determine the detection limit of this PCR assay, it was applied on serial dilutions of genomic DNA from $B$. multivorans R-20526, a strain for which whole-genome sequencing data is available (BioProject PRJNA234537). The mean weight for an AT and GC base pair is 615.3830 Da and 616.3711 Da, respectively [37]. Given the $\mathrm{GC}$ content of this genome of about $68 \%$, and ignoring the presence of modified nucleotides, the mean relative weight of one base pair of R-20526 is $616.0549 \mathrm{Da}$ or $1.023 \times 10^{-9} \mathrm{pg}\left(1 \mathrm{Da}=1.660539 \times 10^{-24} \mathrm{~g}\right)$. Given the genome size of $6.5 \mathrm{Mb}$, one genome of R-20526 contains $6.65 \times 10^{-6} \mathrm{ng}$ of DNA, or $1 \mathrm{ng}$ of DNA contains $1.50 \times$ $10^{5}$ genome equivalents. The undiluted genomic DNA stock of strain R-20526 contained $225 \mathrm{ng} / \mu \mathrm{l} \mathrm{DNA}$, as measured with the Promega QuantiFluor ONE dsDNA system, or $3.38 \times 10^{7}$ genomic DNA equivalents per $\mu \mathrm{l}$. The PCR assay was first applied on a $50 \times$ dilution series (in TE buffer) to find the approximate fading range. The highest $50 \times$ dilution for which an amplicon could be obtained was then used to make a twofold dilution series to find the limit of detection. The PCR assay was performed three times for each dilution and the detection limit was defined as the highest twofold dilution that tested positive in all three runs. Considering the $r e c A$ gene is a single-copy gene for $B$. multivorans R-20526, the detection limit was calculated from the measured DNA concentration and calculated DNA content.

\section{Statistical data analysis}

Statistical data analysis was performed using $\mathrm{R}$ version 3.1.2 in RStudio (version 0.98.1091), with the following packages: car, ggplot2, and MASS. Binomial logistic regression was used to test which variables (type, region, class, $\mathrm{pH}$, temperature) were significant predictor variables for the outcome variable, i.e., B. multivorans detection (Bm). 
Type, class, region, and Bm were coded as factors, and the level with the most cases was chosen as reference category. Temperature and $\mathrm{pH}$ were coded as numeric variables, and centered around the mean to reduce standard error (SE). Backward stepwise model selection was applied to select the best fitting models.

\section{Additional files}

Additional file 1: sampling map. Map showing all sampling locations as produced by the ggmap and ggplot2 packages in $\mathrm{R}$ (own figure). Bm, B. multivorans. (pdf). (PDF 913 kb)

Additional file 2: sample data. Bcc, Burkholderia cepacia complex PCR positive; Bm, B. multivorans PCR positive; NA, not available. WW, West-Vlaanderen; OV, Oost-Vlaanderen; L, Limburg; VB, Vlaams-Brabant; A, Antwerpen. SRW, swimming or recreational water; CRS, canal-river-stream; $\mathrm{O}$, other. (XIsx). (XLSX $17 \mathrm{~kb})$

\section{Abbreviations}

Bcc Burkholderia cepacia complex, CF cystic fibrosis

\section{Acknowledgements}

C. P. is indebted to the Special Research Council of Ghent University.

\section{Funding}

Not applicable.

\section{Availability of data and material}

All data generated or analyzed during this study are included in this published article and its supplementary information files.

\section{Authors' contributions}

CP carried out the sampling and experiments, participated in the statistical data analysis and drafted the manuscript. SD performed the statistical data analysis and participated in critical reading of the manuscript. PV conceived of the study, participated in the design and coordination, and helped writing the manuscript. All authors read and approved the final manuscript.

\section{Authors' information}

Not applicable.

\section{Competing interests}

The authors declare that they have no competing interests.

\section{Consent for publication}

Not applicable (our manuscript does not contain data from any individual person).

\section{Ethics approval and consent to participate}

Not applicable (our manuscript does not report on or involve the use of any animal or human data or tissue).

\section{Author details}

'Laboratory of Microbiology, Department of Biochemistry and Microbiology, Ghent University, Ghent, Belgium. ${ }^{2}$ Department of Sociology, Ghent University, Ghent, Belgium. ${ }^{3}$ Department of Public Administration and Sociology, Erasmus University Rotterdam, Rotterdam, The Netherlands.

Received: 9 December 2015 Accepted: 4 August 2016

Published online: 12 August 2016

\section{References}

1. De Smet B, Mayo M, Peeters C, Zlosnik JEA, Spilker T, Hird TJ, et al. Burkholderia stagnalis sp. nov. and Burkholderia territorii sp. nov., two novel Burkholderia cepacia complex species from environmental and human sources. Int J Syst Evol Microbiol. 2015;65:2265-71. Available from: http:// www.ncbi.nlm.nih.gov/pubmed/25872960.
2. Vandamme P, Peeters C. Time to revisit polyphasic taxonomy. Antonie Van Leeuwenhoek. 2014;106:57-65. Available from: http://www.ncbi.nlm.nih.gov/ pubmed/24633913.

3. Parke JL, Gurian-Sherman D. Diversity of the Burkholderia cepacia complex and implications for risk assessment of biological control strains. Annu Rev Phytopathol. 2001;39:225-58. Available from: http://www.annualreviews.org/ doi/abs/10.1146/annurev.phyto.39.1.225.

4. LiPuma JJ. The changing microbial epidemiology in cystic fibrosis. Clin Microbiol Rev. 2010;23:299-323.

5. De Boeck K, Malfroot A, Van Schil L, Lebecque P, Knoop C, Govan JRW, et al. Epidemiology of Burkholderia cepacia complex colonisation in cystic fibrosis patients. Eur Respir J. 2004;23:851-6. Available from: http://erj.ersjournals. com/lookup/doi/10.1183/09031936.04.00118804.

6. Segonds C, Heulin T, Marty N, Chabanon G. Differentiation of Burkholderia species by PCR-restriction fragment length polymorphism analysis of the $16 \mathrm{~S}$ rRNA gene and application to cystic fibrosis isolates. J Clin Microbiol. 1999;37: 2201-8. Available from: http://www.ncbi.nlm.nih.gov/pubmed/10364586.

7. Biddick R, Spilker T, Martin A, LiPuma JJ. Evidence of transmission of Burkholderia cepacia, Burkholderia multivorans and Burkholderia dolosa among persons with cystic fibrosis. FEMS Microbiol Lett. 2003;228:57-62. Available from: http://femsle.oxfordjournals.org/cgi/doi/10.1016/S03781097(03)00724-9.

8. Whiteford ML, Wilkinson JD, McColl JH, Conlon FM, Michie JR, Evans TJ, et al. Outcome of Burkholderia (Pseudomonas) cepacia colonisation in children with cystic fibrosis following a hospital outbreak. Thorax. 1995;50:1194-8. Available from: http://thorax.bmj.com/cgi/doi/10.1136/thx.50.11.1194.

9. Baldwin A, Mahenthiralingam E, Drevinek P, Pope C, Waine DJ, Henry DA, et al. Elucidating global epidemiology of Burkholderia multivorans in cases of cystic fibrosis by multilocus sequence typing. J Clin Microbiol. 2008;46:2905. Available from: http://jcm.asm.org/cgi/doi/10.1128/JCM.01818-07.

10. Mahenthiralingam E, Baldwin A, Dowson CG. Burkholderia cepacia complex bacteria: opportunistic pathogens with important natural biology. J Appl Microbiol. 2008;104:1539-51.

11. Vanlaere E, Coenye T, Samyn E, Van den Plas C, Govan J, De Baets F, et al. A novel strategy for the isolation and identification of environmental Burkholderia cepacia complex bacteria. FEMS Microbiol Lett. 2005;249:303-7. Available from: http://www.ncbi.nlm.nih.gov/pubmed/16000240.

12. Vermis $K$, Brachkova $M$, Vandamme $P$, Nelis H. Isolation of Burkholderia cepacia complex genomovars from waters. Syst Appl Microbiol. 2003;26: 595-600. Available from: http://www.ncbi.n/m.nih.gov/pubmed/14666988.

13. Ramette A, LiPuma JJ, Tiedje JM. Species abundance and diversity of Burkholderia cepacia complex in the environment. Appl Environ Microbiol. 2005;71:1193-201. Available from: http://aem.asm.org/cgi/doi/10.1128/AEM. 71.3.1193-1201.2005.

14. Fang Y, Xie G-L, Lou M-M, Li B, Muhammad I. Diversity analysis of Burkholderia cepacia complex in the water bodies of West Lake, Hangzhou, China. J Microbiol. 2011;49:309-14. Available from: http://www.ncbi.nlm.nih. gov/pubmed/21538256.

15. LiPuma JJ, Dulaney BJ, McMenamin JD, Whitby PW, Stull TL, Coenye T, et al. Development of rRNA-based PCR assays for identification of Burkholderia cepacia complex isolates recovered from cystic fibrosis patients. J Clin Microbiol. 1999;37:3167-70.

16. Mahenthiralingam E, Bischof J, Byrne SK, Radomski C, Davies JE, Av-gay Y, et al. DNA-based diagnostic approaches for identification of Burkholderia cepacia complex, Burkholderia vietnamiensis, Burkholderia multivorans, Burkholderia stabilis, and Burkholderia cepacia genomovars I and III. J Clin Microbiol. 2000;38:3165-73.

17. Miller SCM, LiPuma JJ, Parke JL. Culture-based and non-growth-dependent detection of the Burkholderia cepacia complex in soil environments. Appl Environ Microbiol. 2002;68:3750-8.

18. Vandamme P, Dawyndt P. Classification and identification of the Burkholderia cepacia complex: past, present and future. Syst Appl Microbiol. 2011;34:87-95.

19. Stoddard SF, Smith BJ, Hein R, Roller BRK, Schmidt TM. rrnDB: improved tools for interpreting rRNA gene abundance in bacteria and archaea and a new foundation for future development. Nucleic Acids Res. 2015;43:D593-8. Available from: http://nar.oxfordjournals.org/lookup/doi/10.1093/nar/gku1201.

20. Drevinek P, Hrbackova H, Cinek O, Bartosova J, Nyc O, Nemec A, et al. Direct PCR detection of Burkholderia cepacia complex and identification of its genomovars by using sputum as source of DNA. J Clin Microbiol. 2002:40:3485-8. Available from: http://jcm.asm.org/cgi/doi/10.1128/JCM. 40.9.3485-3488.2002. 
21. Vermis K, Coenye T, Mahenthiralingam E, Nelis HJ, Vandamme P. Evaluation of species-specific recA-based PCR tests for genomovar level identification within the Burkholderia cepacia complex. J Med Microbiol. 2002;51:937-40.

22. Bergmark L, Poulsen PHB, Al-Soud WA, Norman A, Hansen LH, Sorensen SJ. Assessment of the specificity of Burkholderia and Pseudomonas QPCR assays for detection of these genera in soil using 454 pyrosequencing. FEMS Microbiol Lett. 2012;333:77-84. Available from: http://www.ncbi.nlm.nih.gov/ pubmed/22639954.

23. Moreira D. Efficient removal of PCR inhibitors using agarose-embedded DNA preparations. Nucleic Acids Res. 1998;26:3309-10. Available from: http://nar.oxfordjournals.org/content/26/13/3309.full.pdf.

24. Miller DN. Evaluation of gel filtration resins for the removal of PCR-inhibitory substances from soils and sediments. J Microbiol Methods. 2001;44:49-58. Available from: http://linkinghub.elsevier.com/retrieve/pii/ S0167701200002281.

25. Arbeli Z, Fuentes CL. Improved purification and PCR amplification of DNA from environmental samples. FEMS Microbiol Lett. 2007;272:269-75. Available from: http://femsle.oxfordjournals.org/cgi/doi/10.1111/j. 1574-6968.2007.00764.x.

26. Josephson KL, Gerba CP, Pepper IL. Polmerase chain detection of nonviable bacterial pathogens. Appl Environ Microbiol. 1993;59:3513-5.

27. Fierer N, Jackson RB. The diversity and biogeography of soil bacterial communities. Proc Natl Acad Sci. 2006;103:626-31. Available from: http:// www.pnas.org/content/103/3/626.full.pdf.

28. Rousk J, Baath E, Brookes PC, Lauber CL, Lozupone C, Caporaso JG, et al. Soil bacterial and fungal communities across a pH gradient in an arable soil. ISME J. 2010;4:1340-51. Available from: http://www.nature.com/doifinder/10. 1038/ismej.2010.58.

29. Stopnisek N, Bodenhausen N, Frey B, Fierer N, Eberl L, Weisskopf L. Genuswide acid tolerance accounts for the biogeographical distribution of soil Burkholderia populations. Environ Microbiol. 2014;16:1503-12. Available from: http://www.ncbi.n/m.nih.gov/pubmed/23945027.

30. Raes J, Korbel JO, Lercher MJ, von Mering C, Bork P. Prediction of effective genome size in metagenomic samples. Genome Biol. 2007;8:R10. Available from: http://genomebiology.com/2007/8/1/R10.

31. Konstantinidis KT, Tiedje JM. Trends between gene content and genome size in prokaryotic species with larger genomes. Proc Natl Acad Sci. 2004;101:31605. Available from: http://www.pnas.org/content/101/9/3160.full.pdf.

32. Livermore JA, Emrich SJ, Tan J, Jones SE. Freshwater bacterial lifestyles inferred from comparative genomics. Environ Microbiol. 2014;16:746-58. Available from: http://www.ncbi.nlm.nih.gov/pubmed/23889754.

33. Barberan A, Ramirez KS, Leff JW, Bradford MA, Wall DH, Fierer N. Why are some microbes more ubiquitous than others? Predicting the habitat breadth of soil bacteria. Ecol Lett. 2014;17:794-802.

34. Pitcher DG, Saunders NA, Owen RJ. Rapid extraction of bacterial genomic DNA with guanidium thiocyanate. Lett Appl Microbiol. 1989;8:151-6.

35. Peeters C, Zlosnik JEA, Spilker T, Hird TJ, LiPuma JJ, Vandamme P. Burkholderia pseudomultivorans sp. nov., a novel Burkholderia cepacia complex species from human respiratory samples and the rhizosphere. Syst Appl Microbiol. 2013;36:483-9. Available from: http://www.ncbi.nlm.nih.gov/ pubmed/23867250.

36. Baldwin A, Mahenthiralingam E, Thickett KM, Honeybourne D, Maiden MCJ Govan JR, et al. Multilocus sequence typing scheme that provides both species and strain differentiation for the Burkholderia cepacia complex. J Clin Microbiol. 2005:43:4665-73. Available from: http://jcm.asm.org/cgi/reprint/43/9/4665.pdf.

37. Dolezel J, Bartos J, Voglmayr H, Greilhuber J. Nuclear DNA content and genome size of trout and human. Cytometry. 2003;51A:127-8. Available from: http://www.ncbi.n/m.nih.gov/pubmed/12541287.

\section{Submit your next manuscript to BioMed Central and we will help you at every step:}

- We accept pre-submission inquiries

- Our selector tool helps you to find the most relevant journal

- We provide round the clock customer support

- Convenient online submission

- Thorough peer review

- Inclusion in PubMed and all major indexing services

- Maximum visibility for your research

Submit your manuscript at www.biomedcentral.com/submit 